Earthworm Lumbricus terrestris mediated redistribution of $\mathrm{C}$ and $\mathrm{N}$ into large macroaggregate-occluded soil fractions in fine-textured no-till soils

\title{
Sheehy, Jatta
}

2019-08

Sheehy , J , Nuutinen, V , Six , J , Palojarvi , A, Knuutila , O , Kaseva , J \& Regina , K 2019

, ' Earthworm Lumbricus terrestris mediated redistribution of $C$ and $N$ into large macroaggregate-occluded soil fractions in fine-textured no-till soils ' , Applied Soil Ecology , vol. 140 , pp. 26-34 . https://doi.org/10.1016/j.apsoil.2019.04.004

http://hdl.handle.net/10138/329664

https://doi.org/10.1016/j.apsoil.2019.04.004

cc_by_nc_nd

acceptedVersion

Downloaded from Helda, University of Helsinki institutional repository.

This is an electronic reprint of the original article.

This reprint may differ from the original in pagination and typographic detail.

Please cite the original version. 


\section{Earthworm Lumbricus terrestris mediated redistribution}

\section{3 of $\mathbf{C}$ and $\mathbf{N}$ into large macroaggregate-occluded soil}

\section{4 fractions in fine-textured no-till soils}

6

7 Jatta Sheehy ${ }^{\mathrm{a}}$, Visa Nuutinen ${ }^{\mathrm{a}}$, Johan $\mathrm{Six}^{\mathrm{b}}$, Ansa Palojärvi ${ }^{\mathrm{a}}$, Ossi Knuutila ${ }^{\mathrm{c}}$, Janne Kaseva ${ }^{\mathrm{a}}$,

$8 \quad$ Kristiina Regina ${ }^{a^{*}}$

9

$10 \quad{ }^{a}$ Natural Resources Institute Finland (Luke), FI-31600 Jokioinen, Finland;

$11{ }^{\mathrm{b}}$ Department of Environmental Systems Science, Swiss Federal Institute of Technology,

12 ETH-Zurich, Tannenstrasse 1, 8092 Zurich, Switzerland;

13 'Department of Agricultural Sciences, University of Helsinki, Koetilantie 5, P.O.Box 28,

14 FI-00014 University of Helsinki, Finland

15 *Corresponding author. Tel.: +358295326474. E-mail address: kristiina.regina@luke.fi (K.

16 Regina)

18 Abstract

19 By processing large quantities of crop residues, earthworms enhance the mineralization of

20 organic matter but have also been shown to stabilize soil organic carbon (SOC) into soil

21 fractions like microaggregates $(53-250 \mu \mathrm{m})$ within macroaggregates $(>250 \mu \mathrm{m})$ especially 
in no-till soils. Our objective was to find direct evidence on the impact of an anecic, soil

23 surface-feeding earthworm, Lumbricus terrestris L., on the redistribution of SOC and soil 24 nitrogen $(\mathrm{N})$ into macroaggregate-occluded soil fractions of boreal soils. We sampled soil (0-5 cm depth) from the middens of L. terrestris (mounds of collected residue and surface casts at the openings of its permanent burrows) and the adjacent non-midden (bulk) soil at three no-till sites in southern Finland: two clayey sites (sites 1-2) and one coarse textured site (site 3). Compared to bulk soil, the soil in L. terrestris middens featured general 29 increase in aggregate size and content of SOC and $\mathrm{N}$ within the large macroaggregates $30(>2000 \mu \mathrm{m})$ at the clayey sites. The microaggregates within the large macroaggregates had 31 accumulated more SOC and $\mathrm{N}$ in the midden soil especially at site 1 where $99 \%$ of the 32 difference in total SOC between midden and bulk soil was associated with this type of SOC 33 stabilization. At site 2, the increase in SOC found in the large macroaggregates was 34 counteracted by a decrease in SOC in microaggregates within the small macroaggregates (250-2000 $\mu \mathrm{m})$. No differences in SOC stored in soil fractions were found between midden and non-midden soil at the coarse soil site 3 with higher top soil decomposition rate compared to sites 1 and 2. Across the study sites, the total amount of SOC was $6 \%$ higher in midden soil compared to the bulk soil. These results suggest L. terrestris mediates the storage of SOC and $\mathrm{N}$ into better protected soil fractions in clay soils under boreal conditions.

Keywords: Earthworms; carbon sequestration; nitrogen cycle; soil aggregation; no-till

\section{Introduction}


Earthworms play a key role in soil organic matter dynamics and the regulation of nutrient cycling (Blouin et al., 2013; Filser et al., 2016). They interact with and impact a multitude of soil processes including soil aggregation, decomposition of residues and formation of macropores, which makes earthworms, and the ecosystem services they offer, of interest when developing sustainable agroecosystems (Jones et al., 1994; Lavelle et al.,

51 1997; Fonte et al., 2009; Giannopoulos et al., 2010; Xiang et al., 2018). Earthworms are often the predominant group of soil animals in terms of biomass (Coleman and Crossley, 2004) and they can consume up to $2 \mathrm{t}$ of litter $\mathrm{ha}^{-1} \mathrm{yr}^{-1}$ (Whalen and Parmelee, 2000). Earthworm feeding enhances litter decomposition directly through their metabolism (Curry and Schmidt, 2007) and indirectly by fragmenting the coarse organic matter and increasing its surface area (Blouin et al., 2013). Earthworms egest a mixture of metabolized organic material and mineral soil as sub-surface and surface casts. According to a recent metaanalysis, total organic $\mathrm{C}$, total $\mathrm{N}$ and total $\mathrm{P}$ are $40-48 \%$ higher in casts while mineral $\mathrm{N}$ and available P are increased by $241 \%$ and $84 \%$, respectively (van Groenigen et al. 2019). For the majority of soil fertility relevant properties, the relative difference between casts and the bulk soil ("relative cast fertility") indicates high fertility of casts. Earthworm species can be categorized in three ecological groups based on their feeding habits and the soil environment they occupy (Bouché, 1977; Lavelle and Spain,

64 2001). Anecic species, like L. terrestris, make permanent, typically close to $1 \mathrm{~m}$ deep, 65 vertical burrows (e.g. Nuutinen and Butt, 2003; Don et al., 2008), which open at the soil 66 surface. These species feed on the surface litter which they pull down into their burrows 67 and create litter and cast-made middens within sight on the soil surface (Subler and Kirsch, 68 1998; Nieminen et al., 2015). Epigeic species live near the soil surface feeding on surface 
69 litter while endogeic species mainly reside in the top soil making burrows with varying 70 orientation while feeding on below ground SOM.

Soil macroaggregates $(>250 \mu \mathrm{m})$ and microaggregates $(53-250 \mu \mathrm{m})$ protect soil organic carbon (SOC) within them from mineralization. These soil physical fractions increase the residence time of SOC by both offering physical protection from microbial decomposition and by creating conditions of low oxygen content that significantly slow down the decay of organic matter (Six et al., 2002). The turnover rate of SOC is affected by its distribution among the different aggregate fractions (Six et al., 2000; Bossuyt et al., 2002). Microaggregates are more strongly bound together than macroaggregates and thus offer a more stable long-term storage for SOC (Angers et al., 1997; Six et al., 2002). However, macroaggregates play a key role in providing sites for microaggregate formation 80 (Six et al., 2000).

The soils affected by the casting of anecic earthworms are known to have an increased proportion of larger soil aggregates (Arai et al., 2018; Frazão et al., 2019), however, sometimes at the expense of smaller soil aggregates (Alegre et al., 1996; Lavelle et al., 2004). It has also been suggested that the formation rate of microaggregates within macroaggregates is enhanced by passage through the earthworm gut (Bossuyt et al., 2005; Pulleman et al., 2005). This is enabled when processed organic residues, that are often high in SOC due to food selection, and soil particles mix together within the earthworm gut creating new microaggregates that are excreted in casts (Barois et al., 1993). Linings of the 89 earthworm burrows (Don et al., 2008; Leue et al., 2018) and earthworm-affected soil 90 aggregates (Wu et al., 2018) have been found to have higher SOC content compared to bulk 91 soil. However, while earthworms increase soil aggregation and SOC sequestration in the 92 long term, they enhance litter decomposition and losses of SOC as carbon dioxide in the 4 
93 short term; this time dependence in effect has been discussed as the "earthworm dilemma" 94 by Lubbers et al. $(2013 ; 2017)$.

Effects of earthworms are especially interesting in long-term no-till management which has been found to increase both earthworm numbers and aggregate size (Bai et al., 2018). Enhanced top soil residue availability and low physical disturbance in no-till can increase especially the number of soil surface feeding earthworms, such as Lumbricus terrestris L. (Briones and Smith, 2017) which mix the residues into the soil and thus alter the soil structure and nutrient availability (Thevathasan and Gordon, 2004; Whalen and Fox, 2006; Bai et al., 2018). of earthworms has been gained especially in laboratory incubations (Wu et al., 2017) or

104 field studies in temperate and tropical environments (Blanchart et al., 1999; Fonte and Six, 105 2010; Arai et al., 2018). Boreal conditions with soil frosting, low carbon input in crop residues (Palosuo et al., 2016) and sufficient soil moisture for decomposition throughout most of the year constrain carbon accrual and relatively modest effects of no-till or reduced 108 tillage on SOC stocks have been observed (Sheehy et al., 2015; Singh et al., 2015). The 109 contribution of deep-burrowing earthworms to the processes leading to SOC stabilization in 110 no-till management in boreal conditions is largely unknown. We studied the impact of the 111 only anecic earthworm species found in the arable soils of Finland, L. terrestris, on soil 112 aggregation level and SOC and N division between soil aggregates in three Finnish no-till 113 sites by comparing soil sampled from earthworm middens with the bulk soil. Our aim was 114 to elucidate if the observed no-till induced changes in aggregate size and redistribution of 115 SOC in these soils (Sheehy et al., 2015) could result from earthworm activities. We 116 hypothesized that L. terrestris middens would have a higher content of SOC and $\mathrm{N}$ in the 
117 best protected soil fractions compared to the bulk soil thus providing evidence of the role of

118 earthworms in SOC stabilization in boreal arable soils. As clay soils often are found to 119 favor SOC sequestration, we expected to see more midden-associated SOC in clayey than 120 coarse textured soil.

\section{Material and methods}

\subsection{Study site and management information}

This study took place at three long-term no-till fields in southwestern Finland. Two fields

127 (sites 1 and 2) were located in Jokioinen $\left(60^{\circ} 49^{\prime} \mathrm{N}\right.$ and $\left.23^{\circ} 30^{\prime} \mathrm{E}\right)$ with a yearly average 128 precipitation of $627 \mathrm{~mm}$ and average temperature of $4.6^{\circ} \mathrm{C}$. Soils at both these sites were 129 classified as Vertic Luvic Stagnosol (IUSS Working Group WRB, 2015). The third field 130 (site 3) was classified as Eutric Regosol (WRB) and was located in Säkylä $\left(60^{\circ} 58^{\prime} \mathrm{N}\right.$ and $\left.13122^{\circ} 31^{\prime} \mathrm{E}\right)$ which has a yearly average precipitation of $614 \mathrm{~mm}$ and an average temperature 132 of $4.8^{\circ} \mathrm{C}$. Sites $1-2$ were field experiments (randomized complete-block design with four 133 replicates) and the field of site 3 belonged to a private farmer (plot size 100-250 $\mathrm{m}^{2} ; 4$ 134 pseudoreplicates).

135 No-till practice, in which the crop was sown without prior soil tillage, had been used 136 at the study sites for eleven (sites 1-2) or twelve (site 3) years (Table 1). Spring barley

137 (Hordeum vulgare) was cultivated at sites 1 and 2 and spring turnip rape (Brassica rapa 138 subsp. oleifera) at site 3. However, at site 3, spring barley had been cultivated during the 139 previous years. Fields were sown and fertilized in May. Seeds were directly sown to 3-5 $140 \mathrm{~cm}$ depth with combined drill having triple disc coulters (site 3, row space $15 \mathrm{~cm}$, front 6 
141 single disc coulter is tilling and rear double disc coulter is sowing with roller wheels behind

142 the sowing coulters) or double disc coulters (sites 1 and 2, row space $14.5 \mathrm{~cm}$, packing

143 wheels behind the drill). The direct drills placed the seeds and fertilizer in the same row.

144 The whole annual fertilizer application of $100 \mathrm{~kg} \mathrm{~N} \mathrm{ha}^{-1} \mathrm{yr}^{-1}$ (sites 1 and 2) or $80 \mathrm{~kg} \mathrm{~N} \mathrm{ha}^{-1}$

$145 \mathrm{yr}^{-1}$ (site 3) was made during sowing. Granular ammonium nitrate NPK fertilizer was used

146 at sites 1 and 2 and liquid fertilizer (Urea 32) was used at site 3. Compared to average yield

147 during the past decade, below average yields were harvested in August at all study sites 148 (Table 1).

\subsection{Soil sample collection and analysis}

152 Soil for studying the physical soil fractions was sampled in September 2010 about a month 153 after harvest at all study sites. The samples were taken from L. terrestris middens and 154 surrounding bulk soil (at least $15 \mathrm{~cm}$ from the closest middens) to the depth of $5 \mathrm{~cm}$ with a $1555 \mathrm{~cm}$ diameter soil corer. The midden soil samples included the burrow entrance of $L$. 156 terrestris and were comprised mostly of soil, casts and straw. The bulk soil samples 157 represented the soil without a L. terrestris midden-burrow complex. Four midden soil 158 bulk soil pairs were sampled from four different locations at each study site. The four 159 samples in each location were pooled to form four replicates of large enough samples for 160 soil fractionation.

161 The aggregate size distribution was analyzed by separating different aggregates by 162 wet sieving according to Elliot et al. (1986) and as described by Sheehy et al. (2015). The 163 field-moist soil samples were sieved through an $8 \mathrm{~mm}$ sieve and then air-dried. An $80 \mathrm{~g}$ 164 subsample of soil was taken for the wet sieving which was done through a series of three 7 
165 sieves that separated the samples into four different soil fractions; large macroaggregates 166 (LM; >2000 $\mu \mathrm{m})$, small macroaggregates $(\mathrm{sM} ; 250-2000 \mu \mathrm{m})$, microaggregates $(\mathrm{m}$; 53$167250 \mu \mathrm{m})$ and silt and clay $(\mathrm{s}+\mathrm{c} ;<53 \mu \mathrm{m})$. Prior to wet sieving the samples were submerged 168 into deionized water on top of the $2000 \mu \mathrm{m}$ sieve for a period of $5 \mathrm{~min}$. The sieving was 169 done by manually moving the sieve up and down 50 times during a $2 \mathrm{~min}$ period. The sieve 170 was backwashed and the fraction remaining on top of the sieve was collected in an 171 aluminum pan and oven-dried at $60^{\circ} \mathrm{C}$. Organic material (plant residues) floating on the 172 water after sieving with the $2000 \mu \mathrm{m}$ sieve was discarded as it is not considered SOM by 173 definition. The sieving was similarly repeated with the remaining sieves.

174 Microaggregates within LM and sM fractions were isolated according to Six et al. 175 (2000) and as described in Sheehy et al. (2015). The goal of this method was to break down 176 the macroaggregates while avoiding the breakdown of the released microaggregates. A 177 separate subsample of 10,5 or $3 \mathrm{~g}$, depending on the amount of available material, was 178 taken from LM and sM fractions and was placed on top of a $250 \mu \mathrm{m}$ mesh. The sample was 179 shaken with 50 stainless steel beads (4 $\mathrm{mm}$ diameter) in a reciprocal shaker with a 180 continuous flow of running deionized water until all the macroaggregates were broken 181 down (3-5 min of shaking depending on the soil type). The microaggregates and other 182 released material went through the mesh screen with the running water ending up on a 53 $183 \mu \mathrm{m}$ sieve and were then sieved as in the wet-sieving method. As a result three different 184 fractions were isolated from the macroaggregates: coarse particulate organic matter (cPOM; $185>250 \mu \mathrm{m})$, microaggregates within macroaggregates $(\mathrm{mM} ; 53-250 \mu \mathrm{m})$ and silt and clay $186 \quad(\mathrm{~s}+\mathrm{cM} ;<53 \mu \mathrm{m})$.

187 The mean weight diameter (MWD) of the aggregates, that can be used as an indicator 188 of aggregate stability, was calculated according to van Bavel (1949). Carbon and N content 8 
189 of all fractions from wet sieving and microaggregate isolation were analyzed with a CN-

190 analyzer (ECS 4010, Costech Instruments, USA). The SOC and N content of the different

191 aggregates and the total $\mathrm{C}$ and $\mathrm{N}$ was calculated using the equivalent soil mass method 192 according to Lee et al. (2009) which takes into account the different bulk densities of the 193 soils sampled.

\subsection{Decomposition rate measurements}

197 Decomposition rates of two types of crop residue with different chemical quality, barley 198 (Hordeum vulgare) straw and pea (Pisum sativum) residue, were measured at all study sites 199 from November 2009 to September 2010. Residue bags were installed to three different 200 depths of the bulk soil: on the top of the soil $(0 \mathrm{~cm})$, and buried $10 \mathrm{~cm}$ and $20 \mathrm{~cm}$ deep. 201 Residue bags $(10 \times 15 \mathrm{~cm})$ were made out of polyester mesh $(1 \mathrm{~mm})$ and $5 \mathrm{~g}$ of air dried, untreated barley straw or pea residue as $5 \mathrm{~cm}$ long pieces, was put into each bag. Sides of 203 the bags were stitched together with a serger and a plastic tag was attached with a line. The bags with the residue in them were oven dried overnight at $40^{\circ} \mathrm{C}$ for a final weight. The bags were installed in two rows 4 meters from the end of the study plots and one meter from each side of the plots. The two rows were $50 \mathrm{~cm}$ apart from each other. There were

207 four barley straw bags at each depth and two pea residue bags at each depth for a total of 18 208 residue bags at each study site. Half of these bags were collected at the end of April before 209 the start of the growing season and half were left in the study plots until the end of the 210 growing season (September). Afterwards the residue bags were air dried for a week, the 211 residue samples then moved to paper bags and oven dried at $40^{\circ} \mathrm{C}$ before grinding the 212 samples for analysis. 
213 Barley straw and pea residue in the residue bags were analysed for mass loss. Due to the 1

$214 \mathrm{~mm}$ mesh size, a variable amount of surrounding soil was incorporated into the bags. The

215 mixture of plant residue and soil from the bags was ground and about $2 \mathrm{~g}$ of the ground

216 sample was taken for the loss on ignition (LOI) analysis. The samples were incinerated at

217550 degree $\mathrm{C}$ for $5 \mathrm{~h}$ in a high temperature muffle furnace. This enables calculating the

218 content of organic matter in the samples as the ignition leaves the mineral part of the soil as

219 ash while organic matter is lost. The results from the separate LOI analysis from the

220 original barley straw and pea residue, and the surrounding soil samples, were used for

221 correction (ash free dry weight).

\subsection{Statistical analysis}

Aggregate weights were normally distributed, but distributions of SOC and N were skewed.

226 Linear mixed models with $(\mathrm{C} \& \mathrm{~N})$ and without (aggregate weights) logarithm 227 transformation were used in analysis. The models were fitted by using the residual 228 maximum likelihood (REML) estimation method, having treatment, fraction and field 229 denoted as fixed effects. The effect of treatment (i.e. midden versus surrounding bulk soil 230 (non-midden) was analyzed as repeated measures having heterogeneous compound 231 symmetry (CSH) covariance structure. The model can be expressed in equation form:

235 where $\mu$ is the overall mean, $T_{i}, R_{j}$ and $F_{k}$ are the fixed effects of the treatment, fraction and 236 field, respectively. Two- and three-factor interactions of fixed effects were also included in 10 
237 the model; interaction of the block, $B_{l}$, with other factors $\left(F_{k}, T_{F B} B_{i k l}\right.$ and $\left.R F B_{j k l}\right)$

238 represent the random effects, and $\varepsilon_{\mathrm{ijkl}}$ is the random error term of the model. The random 239 variables were assumed independent and normally distributed. The mean weight diameter 240 (MWD) was analyzed using the same model without the different fractions.

241 The data to calculate effects on the decomposition rate consisted of one dependent variable, 242 decomposed plant material, and five independent variables of site, crop management 243 practice, depth, residue type (barley straw vs. pea residue) and date (season). All 244 independent variables and their two- and three-factor interactions were included in the first 245 model. Eventually, all non-significant $(\alpha=0.05)$ fixed effects were removed from the final 246 model. The model takes into account that residue type and date were repeated measures 247 having unstructured covariance structures (un $\otimes u n$ ). The unstructured covariance structure 248 is the most flexible since it imposes no pattern on the covariances. Thus, all variance and 249 covariance components of residue type and date were estimated, unlike simpler structures 250 constraining some components. This structure is constructed by taking the Kronecker 251 product of an unstructured matrix, modeling covariance across the residue types, with an 252 unstructured matrix, modeling covariance across dates (Galecki, 1994). 255 residuals were also plotted against the fitted values. These plots indicated that the 256 assumptions of the models are adequate. Comparison of means was done with the Tukey257 Kramer post hoc test. A significance level of $\alpha=0.05$ was used in all analysis. Degrees of 258 freedom were calculated using Kenward-Roger method. The analyses were performed 
using the MIXED procedure of the SAS Enterprise Guide 5.1 (SAS Institute Inc., Cary,

$260 \mathrm{NC}, \mathrm{USA})$.

\section{Results}

3.1 Aggregate weight and stability

There were more large macroaggregates (LM) in the soil from L. terrestris middens than in the surrounding bulk soil at study sites 1 and 2 ( $\mathrm{p}=0.008$ and $<0.001$ respectively) but less small macroaggregates $(\mathrm{sM})$ at site $2(\mathrm{p}<0.0001)$ (Fig. 1). The greatest portion of LM was

269 found in the middens of site 2 where they represented $35 \%$ of the soil mass. The amount of 270 free microaggregates $(\mathrm{m})$ in the soil was lower $(\mathrm{p}=0.006)$ in midden soil compared to bulk

271 soil at site 1 . No differences were found between midden soil and bulk soil in the different 272 fractions in the coarse soil of site 3.

The proportional weight of coarse particulate organic matter (cPOM) from LM 274 fractions was higher within the midden soil compared to bulk soil at site 2 ( $\mathrm{p}=0.002)$ (Fig. 275 1). On the other hand, the proportional weight of microaggregates formed within LM 276 fractions $(\mathrm{mM})$ was lower in midden soil than surrounding bulk soil at site $2(\mathrm{p}=0.005)$. 277 Within sM fraction, the proportional weight of cPOM was higher in the middens versus 278 surrounding bulk soil at site $2(\mathrm{p}=0.012)$ and lower at site $1(\mathrm{p}=0.028)$. The proportion of $279 \mathrm{mM}$ fraction within $\mathrm{sM}$ fraction was higher in the middens at site $1(\mathrm{p}<0.001)$, lower in the 280 middens at site $2(\mathrm{p}=0.031)$ and without a difference at site 3 . As a proportion of the whole 281 soil, the total $\mathrm{mM}$ fraction from LM and sM was $6-45 \%$ higher in midden soil at all sites 282 (results not shown). 
The MWD of aggregates was on average $20 \%$ higher across all study sites in $L$.

284 terrestris middens compared to the surrounding soil (site 1: $35 \%$; site 2: $21 \%$; site 3: $3 \%$ )

285 (Fig. 2). MWD was significantly higher in the middens versus surrounding bulk soil at the 286 clayey sites 1 and 2 ( $\mathrm{p}=0.001$ and $\mathrm{p}=0.002$ respectively), but not at the coarse textured site 2873 (Fig. 2).

\subsection{Soil carbon}

291 The total SOC content of the 0-5 cm layer was of the same magnitude at all sites (Table 2).

292 The midden associated soil had higher concentration of SOC than the bulk soil when 293 analyzed across all sites $(\mathrm{p}=0.0231)$. Within each single field, the total SOC did not differ 294 between midden and non-midden soil.

295 Enrichment of SOC per area in the soil sampled from the middens was found only in 296 LM fractions at sites 1 and 2 ( $<<0.001$ in both) (Table 2). For the fractions isolated from 297 within LM (Fig. 3), there were higher SOC contents in midden soil compared to bulk soil at 298 all study sites in $\mathrm{cPOM}(\mathrm{p}<0.001)$, at sites 1 and 2 in $\mathrm{mM}$ fraction $(\mathrm{p}=0.014$ and $\mathrm{p}<0.001$, 299 respectively) and in $\mathrm{s}+\mathrm{c}$ fraction ( $\mathrm{p}=0.011$ and $\mathrm{p}<0.001$, respectively). Within $\mathrm{sM}$ fractions, 300 a decrease of SOC in middens was found in $\mathrm{mM}$ fraction at site $2(\mathrm{p}=0.025)$.

\subsection{Soil nitrogen}

303

304 The amount of total $\mathrm{N}$ in midden soil versus bulk soil did not differ at any sites (results not 305 shown). However, higher $\mathrm{N}$ content in large macroaggregates in midden soil versus 306 surrounding bulk soil was found at the clayey sites 1 and $2(\mathrm{p}<0.001)$ (Table 3$)$. No 13 
changes in $\mathrm{N}$ content were found at site 3. Differences were found, however, in the $\mathrm{N}$ levels

308 between different fields. For example, site 1 had more $\mathrm{N}$ in the top soil than sites 2 or 3 309 ( $\mathrm{p}=0.003$ and $\mathrm{p}=0.011$ respectively) (results not shown).

310 Nitrogen content in cPOM within LM fractions was higher in midden soil compared 311 to bulk soil at sites 1 and $2(\mathrm{p}<0.001)$ (Table 3). At these sites the cPOM-N content was 33126 times higher in middens than bulk soil. More $\mathrm{N}$ was also found in midden versus 313 surrounding bulk soil in LM-occluded microaggregates at site $2(\mathrm{p}=0.005)$ and silt and clay 314 fraction at sites 1 and $2(\mathrm{p}=0.04$ and $\mathrm{p}=0.001$ respectively). No differences in soil $\mathrm{N}$ content 315 were found in small macroaggregate-occluded fractions between midden and bulk soil.

316 The $\mathrm{C}: \mathrm{N}$ ratio of the soil at $0-5 \mathrm{~cm}$ depth varied between 11.8 and 13.1 and did not 317 differ between the midden soil and surrounding bulk soil at any study site.

\subsection{Decomposition rate of barley straw and pea residue}

321 More residue decomposed from the pea residue bags compared to the barley straw bags at 322 sites 1 and $2(\mathrm{p}<0.001)($ Fig. 4a). A significant difference in the decomposition rate at all 323 sites was found between the residue bags on the top soil versus under 10 or $20 \mathrm{~cm}$ of soil 324 with an increasing trend in decomposition rate deeper in the soil profile $(\mathrm{p}<0.001)$ (Fig. 4b).

325 Differences between the two deeper layers were smaller but still significant at sites 1 and 3 $326(\mathrm{p}=0.04 ; \mathrm{p}=0.004)$. Over $65 \%$ of both barley straw and pea residue decomposed at the 20 $327 \mathrm{~cm}$ depth within a year. Sites differed from each other in their decomposition rate in the 328 topsoil $(\mathrm{p}=0.017)$ where site 3 had the highest decomposition rate. No difference in the 329 decomposition rate was found between sites in the other two soil layers indicating that the 330 decomposition rate does not increase as fast with increasing depth at site 3 compared to the 14 
331 other two sites. However, site 1 had a higher decomposition rate of pea residue compared to

332 site $3(\mathrm{p}=0.042)$. Decomposition rate was lower at all depths during the cold winter months 333 with average decomposition rates of only $0.09 \%$ per day compared to $0.17 \%$ per day during 334 the growing season $(\mathrm{p}<0.001)$ (Fig. $4 \mathrm{c})$. Lowest decomposition rate was found at $0 \mathrm{~cm}$ at 335 site 1 where only $14 \%$ of the barley straw was decomposed in the first 6 months after 336 installing the bags.

\section{Discussion}

\subsection{Aggregate stability and aggregate-associated SOC}

342 The observations of increased amount of LM and higher MWD in the midden soil 343 compared to bulk soil point to anecic earthworms having a role in the development of soil 344 aggregation in the clay soils. Our results are supported by several field and laboratory 345 studies where earthworms have enhanced soil aggregation (Blanchart et al., 1999; Bossuyt 346 et al., 2004; Shipitalo and Le Bayon, 2004; Fonte and Six, 2010; Arai et al., 2018; Frazão et 347 al., 2019). The local effect of L. terrestris was also seen as higher SOC content in the 348 middens. In a recent meta-analysis this was the case in the casts of L. terrestris and the 349 epigeic species Lumbricus rubellus unlike the casts of two endogeic species (van Groenigen 350 et al., 2019).

351 The total SOC content of the midden-associated soil compared to the bulk soil was on 352 average $8 \%$ higher at the clayey sites and 3\% higher for the coarse textured soil. These 353 results are in accordance with several studies indicating higher SOC sequestration rates in 354 soils with higher clay content (e.g. Leifeld et al., 2005; Heikkinen et al., 2013). Better 15 
355 protection of SOC in clayey soils is often attributed to less accessible soil pores for 356 microbes and SOC binding to mineral surfaces (Strong et al., 2004; von Lützow et al., 357 2006; Simonetti et al., 2017).

358 Neither the weights of aggregate fractions nor the SOC content differed between middens 359 and bulk soil of Site 3 with coarse soil texture. The tendency to form aggregates is 360 generally lower in coarse compared to finer textured soils (Simonetti et al., 2017; Schapel 361 et al., 2019). Some studies have shown that rapid breakdown of the newly formed 362 aggregates may occur if increased amount of earthworm activity also enhances the 363 mineralization of polysaccharides and other organic gluing compounds (Guggenberger et 364 al., 1996; Ge et al., 2001). This may be the case with our coarse soil that also had high 365 decomposition rate of top soil litter. Due to the small mesh size of residue bags used, the 366 measured decomposition was obviously not directly driven by earthworm feeding but the 367 observed differences between midden and bulk soil are likely the combined result of $L$. 368 terrestris activity and other biological activity. Middens of L. terrestris have been found to 369 accumulate coarse litter and maintain soil moisture (Subler and Kirsch, 1998; Nieminen et 370 al., 2015) as well as favor the activities of microbes (Aira et al., 2009) and fauna (Schrader 371 and Seibel, 2001; Butt and Lowe, 2007; Eisenhauer, 2010; Nieminen et al., 2015; Stroud et 372 al., 2016). On the same three no-till sites, Sipilä et al. (2012) found strong soil fungistasis 373 activity, inhibition of fungal growth related to high microbial biomass, with strongest mean 374 activity at site 3 . This together with the high decomposition rate in the top soil points to the 375 possibility that in this coarse textured soil, aggregation is so weak that the enhanced 376 decomposition negates the potential earthworm-induced increase of SOC stabilization.

377 Part of the observed increase in the LM fraction can likely be explained by the 378 smaller fractions growing in size. Indication of this was the earthworm-induced 16 
379 redistribution of SOC from $\mathrm{SM}$ fraction to $\mathrm{LM}$ fraction in the middens. The SOC content of 380 the middens was $11 \%$ higher in the LM fractions and $6 \%$ lower in the sM fraction 381 compared to bulk soil. These findings are similar to results presented by Fonte and Six 382 (2010) who found a redistribution of SOC into large macroaggregates and the 383 microaggregates within them by earthworms. Similarly, in Peruvian Amazonia, endogeic 384 earthworms increased the proportion of large macroaggregates $(>2 \mathrm{~mm})$ with almost $6 \%$ at 385 the expense of smaller aggregates $(<0.5 \mathrm{~mm})$ that decreased by $8 \%$ after six successive crop 386 cycles (Lavelle et al., 2004).

387 Our results suggest that the presence of $L$. terrestris increases the potential of boreal 388 agricultural soils to store SOC within large macroaggregate-occluded microaggregates. In 389 the clay soils, $44-53 \%$ of the observed difference in SOC stored in large macroaggregates 390 between $L$. terrestris midden soil and bulk soil (Table 2) was found in the microaggregates 391 isolated from them (Fig. 3). This highlights the importance of this fraction as a microsite 392 for SOC sequestration (Six and Paustian, 2014). SOC stabilization in large macroaggregate393 occluded microaggregates was significant at both clay soil sites but at site 2 the increase 394 was counteracted by a decrease in the amount of SOC in small microaggregate-occluded 395 microaggregates. In contrast, the significance of free microaggregates for SOC storage was 396 small in our study.

397 Our results represent the situation in soil in autumn, the period of abundant crop 398 residues and high earthworm activity and thus the results do not represent the average 399 annual situation. Although the biological decomposition in winter is half of the rate in 400 summer (Fig. 4c), there are more physical forces breaking down aggregates in the winter 401 time, particularly the frequent freezing and thawing of the soil that can reduce MWD to half 402 of the autumn values (Edwards, 2013). Even though the increased earthworm midden 17 
associated aggregation level is potentially beneficial in the short-term it may not be enough

404 to create long-term SOC accumulation. Don et al. (2008) concluded that the L. terrestris

405 burrow associated increase in topsoil SOC may be a short-term one, as their study showed 406 that the walls of earthworm-occupied burrows had up to three times higher values of SOC 407 than abandoned earthworm burrows. Fonte and Six (2010) argued that since most of the 408 SOC in earthworm casts is associated with macroaggregate-occluded microaggregates the 409 rate of decomposition in these casts would, with time, possibly decrease to a level below 410 the level of non-ingested soil.

411 Even though there was an increase in the topsoil SOC content in the middens across 412 all sites, this may not be relevant for the SOC sequestration at field scale. Previous studies 413 have shown that the total density of earthworm burrows in the no-till plots of these study 414 sites were higher in comparison to conventionally tilled plots (Regina and Alakukku, 415 2010), but the total SOC stocks did not differ between the treatments (Sheehy et al., 2013).

416 This is in line with the meta-analysis by Lubbers et al. (2013) where no earthworm-induced 417 total SOC increase was found. However, the results of this study suggest that the presence 418 of anecic earthworms predicts increased chances to develop relatively stable sites for SOC 419 storage especially as the continuation of no-till enables further increase of earthworm 420 numbers.

\subsection{Nitrogen content and aggregate-associated $N$}

424 Nitrogen allocation in soil fractions followed closely the trends observed for SOC. Nitrogen 425 levels were markedly higher in the middens of the clayey soils, especially within the coarse 426 particulate organic matter and microaggregate fractions within large macroaggregates; this 18 
was accompanied by an increase in the amount of the large macroaggregates in midden

428 soil. This underlines L. terrestris's ability to accumulate $\mathrm{N}$ within soil particles that are 429 more resistant to decomposition, especially in clayey soils. On the other hand, the total 430 production of mineral $\mathrm{N}$ by the earthworm community can be as high as $74 \mathrm{~kg} \mathrm{ha}^{-1} \mathrm{yr}^{-1}$ 431 (Whalen and Parmelee, 2000; Lavelle et al., 2004) which, for instance, almost equals the 432 average amount of mineral $\mathrm{N}$ added annually by farmers in Finland. Integration of $\mathrm{N}$ into 433 macroaggregate-occluded microaggregates at these sites may counteract the $\mathrm{N}$ 434 mineralization effect of earthworms and slow down the $\mathrm{N}$ cycle in the top soil. The net 435 effect of earthworms for $\mathrm{N}$ cycling in the soil can e.g. determine the nutrient leaching 436 potential of the soil. The presence of earthworms can increase (Dominguez et al., 2004) or 437 decrease (Shuster et al., 2002) N leaching and it has been suggested that there is a threshold 438 value of earthworm density above which the positive effects of increased density turn to 439 increased leaching potential (Shuster et al., 2002).

$440 \quad$ No L. terrestris midden related changes in total $\mathrm{N}$ concentration were observed at site 4413 . This could be partly due to the higher microbial activity and decomposition rate on the 442 top soil at this site compared to the clayey sites as well as a lesser amount of existing fine 443 soil particles. It is also possible that in this coarse textured soil the positive effect of 444 earthworms on $\mathrm{N}$ mineralization is accompanied by accelerated rates of denitrification 445 within earthworm casts. This is supported by a study conducted at site 3 in 2008 that found 446 higher flux rates of nitrous oxide, accompanied by increased $\mathrm{N}$ mineralization rates, around 447 L. terrestris middens compared to surrounding soil (Nieminen et al., 2015).

448 Accumulation of $\mathrm{N}$ in the top-soil of no-till systems has been observed in many 449 studies (Campbell et al., 1996; Spargo et al., 2008). Also, Giannopoulos et al. (2010) found 450 that increased $\mathrm{N}$ incorporation into both macroaggregates $(>250 \mu \mathrm{m})$ and microaggregates 19 
$451 \quad(53-250 \mu \mathrm{m})$ was higher when residues were added as a residue layer on the top of the soil

452 instead of incorporating them into the soil. Sheehy et al. (2013) did not, however, observe

453 any consistent increase in the amount of total $\mathrm{N}$ in the $0-20 \mathrm{~cm}$ layer in no-till versus 454 conventionally tilled soil at any of these sites. Protecting $\mathrm{N}$ into macroaggregate-occluded 455 microaggregates would be beneficial, especially in fields with high or moderate $\mathrm{N}$ leaching 456 potential. There are indications of higher density of L. terrestris individuals and biomass in 457 no-till compared to tilled plots at site 2 (unpublished results). This together with higher 458 levels of large macroaggregate-occluded $\mathrm{N}$ in L. terrestris middens at the clayey sites found 459 in this study, suggests that $\mathrm{N}$ cycling slows down in no-till cultivation.

460

461 5. Conclusions

463 In line with our hypotheses, this study confirmed that L. terrestris mediates changes in soil 464 structure and SOC distribution by creating a more opportune environment for enhanced 465 storage of SOC and N into large macroaggregate-occluded fractions in boreal no-tilled clay 466 soils. Even though the measured effects are local and restricted to middens the results 467 suggest that natural L. terrestris densities in long-term no-till management eventually have 468 the ability to enhance soil macroaggregation and SOC stock also in field scale. This study 469 corroborated our view that earthworms are essential modifiers of soil aggregate structure 470 and associated carbon storage not only in temperate and tropical but also in boreal arable 471 soils. 
475 This study was funded by Maj and Tor Nessling Foundation, Emil Aaltonen Foundation, 476 Häme Cultural Foundation and Natural Resources Institute Finland and was done in cooperation with University of Helsinki, Finland and University of California, Davis, USA.

478 Many thanks to the staff of Natural Resources Institute Finland, Sirkku Manninen and 479 Laura Alakukku for all the support and advice throughout the process. Special thanks to all 480 the people in the Agroecology lab in Davis, CA. We are also thankful to farmer Timo 481 Rouhiainen who gave us the opportunity to use his field in this study.

\section{References}

Aira, M., McNamara, N.P., Piearce, T.G., Dominguez, J., 2009. Microbial communities of Lumbricus terrestris L. middens: structure, activity, and changes through time in relation to earthworm presence. J. Soil Sediment 9, 54-61.

Arai, M., Miura, T., Tsuzura, H., Minamiya, Y., Kaneko, N., 2018. Two-year responses of earthworm abundance, soil aggregates, and soil carbon to no-tillage and fertilization. Geoderma 332, 135-141.

Alegre, J., Pashanasi, B., Lavelle, P., 1996. Dynamics of soil physical properties in Amazonian agroecosystems inoculated with earthworms. Soil Sci. Soc. Am. J. 60, 1522-1529.

Angers, D.A., Bolinder, M.A., Carter, M.R., Gregorich, E.G., Drury, C.F., Liang, B.C., Voroney, R.P., Simard, R.R., Donald, R.G., Beyaert, R.P., Martel, J., 1997. Impact of tillage practices on organic carbon and nitrogen storage in cool, humid soils of eastern Canada. Soil Till. Res. 41, 191-201.

Bai, Z., Caspari, T., Ruiperez Gonzalez, M., Batjes, N.H., Mäder, P., Bünemann, E.K., de Goede, R., for Europe and China. Agr. Ecosyst. Environ. 265, 1-7.

Barois, I., Villemin, G., Lavelle, P., Toutain, F., 1993. Transformation of the soil structure through Pontosolex corethurus (Oligochaeta) intestinal tract. Geoderma 56, 57-66. 
Blanchart, E., Albrecht, A., Alegre, J., Duboisset, A., Gilot, C., Pashanasi, B., Lavelle, P., Brussaard, L., 1999. Effects of earthworms on soil structure and physical properties, in: Lavelle, P., Brussaard, L., Hendrix, P. (Eds.), Earthworm management in tropical agroecosystems. CAB International, Oxford, UK, pp. 149-171.

Blouin, M., Hodson, M.E., Delgado, E.A., Baker, G., Brussaard, L., Butt, K.R., Dai, J., Dendoovern, L., Peres, G., Tondoh, J.E., Cluzeau, D., Brun, J.-J., 2013. A review of earthworm impact on soil function and ecosystem services. Eur. J. Soil Sci. 64, 161-182.

Bossuyt, H., Six, J., Hendrix, P.F., 2002. Aggregate-protected carbon in no-tillage and conventional tillage agroecosystems using carbon-14 labeled plant residue. Soil Sci. Soc. Am. J. 66, 1965-1973.

Bossuyt, H., Six, J., Hendrix, P.F., 2004. Rapid incorporation of fresh residue-derived carbon into newly formed stable microaggregates within earthworm casts. Eur. J. Soil Sci. 55, 393-399.

Bossuyt, H., Six, J., Hendrix, P.F., 2005. Protection of soil carbon by microaggregates within earthworm casts. Soil Biol. Biochem. 37, 251-258.

Bouché, M.B., 1977. Strategies lombriciennes, in: Lohm, U., Persson, T. (Eds.), Soil Organisms as Components of Ecosystems vol. 25, Stockholm, pp. 122-132.Briones, M.J.I., Schmidt O, 2017. Conventional tillage decreases the abundance and biomass of earthworms and alters their community structure in global meta-analysis. Global Change Biology 23, 4396-4419.

Butt, K.R., Lowe, C.N., 2007. Presence of earthworm species within and beneath Lumbricus terrestris L. middens. Eur. J. Soil Biol. 43, Supplement 1, S57-S60.

Campbell, C.A., McConkey, B.G., Zentner, R.P., Sellers, F., Curtin, D., 1996. Long-term effects of tillage and crop rotations on soil organic $\mathrm{C}$ and total $\mathrm{N}$ in a clay soil in southwestern Saskatchewan. Can. J. Soil

524 Curry, J.P., Schmidt, O., 2007. The feeding ecology of earthworms - A review. Pedobiologia 50, 463-477.

525 Don, A., Steinberg, B., Schöning, I., Pritsch, K., Joschko, M., Gleixner, G., 2008. Organic carbon sequestration in earthworm burrows. Soil Biol. Biochem. 40, 1803-1812. 
Dominguez, J., Bohlen, P.J., Parmelee, R.W., 2004. Earthworms increase nitrogen leaching to greater soil depths in row crop agroecosystems. Ecosystems 7, 672-685.

529 Edwards, L.M., 2013. The effects of soil freeze-thaw on soil aggregate breakdown and concomitant sediment flow in Prince Edward Island: A review. Can. J. Soil Sci. 93, 459-472. https://doi.org/10.4141/cjss2012-

532 Eisenhauer, N., 2010. The action of an animal ecosystem engineer: identification of the main mechanisms of earthworm impacts on soil microarhropods. Pedobiologia 53, 343-352.

534 Elliott, E.T., 1986. Aggregate structure and carbon, nitrogen, and phosphorus in native and cultivated soils. Soil Sci. Soc. Am. J. 50, 627-633.

Filser, J., Faber, J.H., Tiunov, A.V., Brussaard, L., Frouz, J., De Deyn, G., Uvarov, A.V., Berg, M.P., Lavelle, models. Soil 2, 565-582.

Fonte, S. J., Winsome, T., Six, J., 2009. Earthworm populations in relation to soil organic matter dynamics and management in California tomato cropping systems. Appl. Soil Ecol. 41, 206-214.

Fonte, S.J., Six, J., 2010. Earthworms and litter management contributions to ecosystem services in a tropical agroforestry system. Ecol. Appl. 20, 1061-1073.

Frazao, J., de Goede, R.G.M., Capowiez, Y., Pulleman, M.M., 2019. Soil structure formation and organic matter distribution as affected by earthworm species interactions and crop residue placement. Geoderma $338,453-463$.

Galecki, A.T., 1994. General class of covariance structures for two or more repeated factors in longitudinal data analysis, Commun Stat Theory Methods. 23:11, 3105-3119. https://doi.org/10.1080/03610929408831436. manure- and inorganic-fertilizer amended agroecosystems influenced by age and depth. Pedobiologia 45, $12-26$.

Giannopoulos, G., Pulleman, M.M., van Groenigen, J.W., 2010. Interactions between residue placement and earthworm ecological strategy affect aggregate turnover and $\mathrm{N}_{2} \mathrm{O}$ dynamics in agricultural soils. Soil Biol. Biochem. 42, 618-625. 
Guggenberger, G., Thomas, R.J., Zech, W., 1996. Soil organic matter within earthworm casts of an anecicendogeic tropical pasture community, Colombia. Appl. Soil Ecol. 3, 263-274.

Heikkinen J., Ketoja E., Nuutinen V., Regina K., 2013. Declining trend of carbon in Finnish cropland soils in 1974-2009. Glob. Change Biol. 19, 1456-1469.

IUSS Working Group WRB, 2015. World Reference Base for Soil Resources 2014, update 2015, International soil classification system for naming soils and creating legends for soil maps. World Soil Resources Reports No. 106. FAO, Rome.

Jones, C.G., Lawton, J.H., Shachak, M., 1994. Organisms as ecosystem engineers. Oikos 69, 373-386.

Lavelle, P., Bignell, D., Lepage, M., Wolters, V., Roger, P., Ineson, P., Heal, O.W., Dhillion, S., 1997. Soil function in a changing world: the role of invertebrate ecosystem engineers. Eur. J. Soil Biol. 33, 159-193.

Lavelle, P., Spain, A.V., 2001. Soil Ecology. Kluwer Scientific Publications, Amsterdam.

Lavelle, P., Charpentier, F., Villenave, C., Rossi, J., Derouard, L., Pashanasi, B., Andre, J., Ponge, J., Bernier, N., 2004. Effects of earthworms on soil organic matter and nutrient dynamics at a landscape scale over decades, in: Edwards, C.A. (Eds.), Earthworm Ecology. CRC Press, Boca Raton, pp. 145-160.

Lee, J., Hopmans, J.W., Rolston, D.E., Baer, S.G., Six, J., 2009. Determining soil carbon stock changes: Simple bulk density corrections fail. Agr. Ecosyst. Environ. 134, 251-256.

Leifeld, J., Bassin, S., Fuhrer, J., 2005. Carbon stocks in Swiss agricultural soils predicted by land-use, soil characteristics, and altitude. Agr. Ecosyst. Environ., 105, 255-266.

Leue, M., Wohld, A., Gerke, H.H., 2018. Two-dimensional distribution of soil organic carbon at intact macropore surfaces in BT-horizons. Soil Till. Res. 176, 1-9.

Lubbers, I.M., van Groenigen, K.J., Fonte, S.J., Six, J., Brussaard, L., van Groenigen, J.W., 2013. Greenhouse-gas emissions from soils increased by earthworms. Nat. Clim. Change 3, 187-194.

Lubbers, I.M., Pulleman, M.M., van Groenigen, J.W. 2017. Can earthworms simultaneously enhance decomposition and stabilization of plant residue carbon? Soil Biol. Biochem., 105, 12-24.

Nieminen, M., Hurme T., Mikola J., Regina K., Nuutinen V., 2015. Impact of earthworm Lumbricus terrestris living sites on the greenhouse gas balance of no-till arable soil. Biogeosciences 12, 5481-5493.

Nuutinen, V., Butt, K.R., 2003. Interaction of Lumbricus terrestris L. burrows with field subdrains. Pedobiologia, 47, 578-581. 
Palosuo T., Heikkinen J., Regina K., 2016. Method for estimating soil carbon stock changes in Finnish mineral cropland and grassland soils. Carbon Management 6, 207-220.

585 Pulleman, M.M., Six, J., Uyl, A., Marinissen, J.C.Y., Jongmans, A.G., 2005. Earthworms and management affect organic matter incorporation and microaggregate formation in agricultural soils. Appl. Soil Ecol.

588 Regina, K., Alakukku, L., 2010. Greenhouse gas fluxes in varying soil types under conventional and notillage practices. Soil Till. Res. 109, 144-152.

Schapel, A., Marschner, P., Churchman, J., 2019. Influence of clay clod size and number for organic carbon distribution in sandy soil with clay addition. Geoderma 335, 123-132.

Schrader, S., Seibel, C., 2001. Impact of cultivation management in an agroecosystem on hot spot effects of earthworm middens. Eur. J. Soil Biol. 37, 309-313.

Sheehy, J., Six, J., Alakukku, L., Regina, K., 2013. Fluxes of nitrous oxide in tilled and no-tilled boreal arable soils. Agr. Ecosyst. Environ. 164, 190-199.

Sheehy, J., Regina, K., Alakukku, L., Six, J., 2015. Impact of no-till and reduced tillage on aggregation and aggregate-associated carbon in Northern European agroecosystems. Soil Till Res., 150, 107-113.

598 Simonetti, G., Francioso, O., Dal Ferro, N., Nardi, S., Berti, B., Morari, F., 2017. Soil porosity in physically separated fractions and its role in SOC protection. J. Soils Sediments 17, 70-84.

600 Singh P., Heikkinen J., Ketoja E., Nuutinen V., Palojärvi A., Sheehy J., Esala M., Mitra S., Alakukku L.,

601 Regina K., 2015. Tillage and crop residue management methods had minor effects on the stock and stabilization of topsoil carbon in a 30-year field experiment. Science of the Total Environment 518-519, 337-344.

604 Sipilä, T. P., Yrjälä, K., Alakukku, L., Palojärvi, A., 2012. Cross-site soil microbial communities under tillage 605 regimes: fungistasis and microbial biomarkers. Appl. Environ. Microb. 78, 8191-8201.

606 Shipitalo, M.J., Le Bayon, R.C., 2004. Quantifying the effects of earthworms on soil aggregation and 200. 

abundance affected runoff volume and nutrient loss in a tilled-corn agroecosystem. Biol. Fertil. Soils 35,

$611320-327$.

612 Six, J., Elliott, E.T., Paustian, K., 2000. Soil macroaggregate turnover and microaggregate formation: a

613 mechanism for C sequestration under no-tillage agriculture. Soil Biol. Biochem. 32, 2099-2103.

614 Six, J., Callewaert, P., Lenders, S., De Gryze, S., Morris, S.J., Gregorich, E.G., Paul E.A., Paustian, K., 2002.

615 Measuring and understanding carbon storage in afforested soils by physical fractionation. Soil Sci. Soc.

$616 \quad$ Am. J. 66, 1981-1987.

617 Six, J., Paustian, K., 2014. Aggregate-associated soil organic matter as an ecosystem property and

618 measurement tool. Soil Biol. Biochem. 68, A4-A9.

619 Spargo, J.T., Alley, M.M., Follett, R.F., Wallace, J.V., 2008. Soil nitrogen conservation with continuous notill management. Nutr. Cycl. Agroecosys. 82, 283-297.

621 Subler, S. Kirsch, A.S., 1998. Spring dynamics of soil carbon, nitrogen and microbial activity in earthworm middens in a notill cornfield. Biol. Fert. Soils 26, 243-249.

Stroud, J.L., Irons. D., Carter, J.E., Watts, C.W., Murray, P.J., Norris, S.L., Whitmore, A.P., 2016. Lumbricus terrestris middens are biological hotspots in a minimum tillage arable ecosystem. Appl. Soil Ecol. 105, $31-35$.

Thevathasan, N.V., Gordon, A.M., 2004. Ecology of tree intercropping systems in the North temperate region: experiences from southern Ontario, Canada. Agroforest. Syst. 61-62, 257-268.

629 van Bavel, C.H.M., 1949. Mean weight-diameter of soil aggregates as a statistical index of aggregation. Soil 630 Sci. Soc. Am. Pro. 14, 20-23.

631 van Groenigen, J.W., Lubbers, I.M., Vos, H.M.J., Brown, G.G., De Deyn, G.B., van Groenigen, K.J., 2014. 632 Earthworms increase plant production: a meta-analysis. Sci. Rep. 4, 6365.

633 van Groenigen, J.W., van Groenigen, K.J., Koopmans, G.F., Stokkermans, L., Vos, H.M.J., Lubbers, I.M., 634 2019. How fertile are earthworm casts? A meta-analysis. Geoderma 338, 525-535. 
635 von Lützow, M., Kögel-Knabner, I., Ekschmitt, K., Matzner, E., Guggenberger, G., Marschner B., Flessa, H., 636 2006. Stabilization of organic matter in temperate soils: mechanisms and their relevance under different 637 soil conditions - a review. Eur J. Soil Sci. 57, 426-445.

638 Whalen, J.K., Parmelee, R.W., 2000. Earthworm secondary production and N flux in agroecosystems: a 639 comparison of two approaches. Oecologia 124, 561-573.

640 Whalen, J.K., Fox, C.A. 2006. Diversity of lumbricid earthworms in temperate agroecosystems, in: Benckiser, 641 G., Schnell, S. (Eds.), Biodiversity in Agricultural Production Systems. CRC, Taylor \& Francis, Boca 642 Raton, pp. 249-261.

643 Wu, Y., Shaaban, M., an Peng, Q., Zhou, A., Hu, R., 2018. Impacts of earthworm activity on the fate of straw 644 carbon in soil: a microcosm experiment. Env. Sci. Poll. Res. 25, 11054-11062.

645 Xiang, H., Guo, L., Zhang, J., Zhao, B., Wei, H. 2018. In Situ Earthworm Breeding to Improve Soil 646 Aggregation, Chemical Properties, and Enzyme Activity in Papayas. Sustainability 10, 1193; https://doi:10.3390/su10041193www.mdpi.com/journal/sustainability.

648 


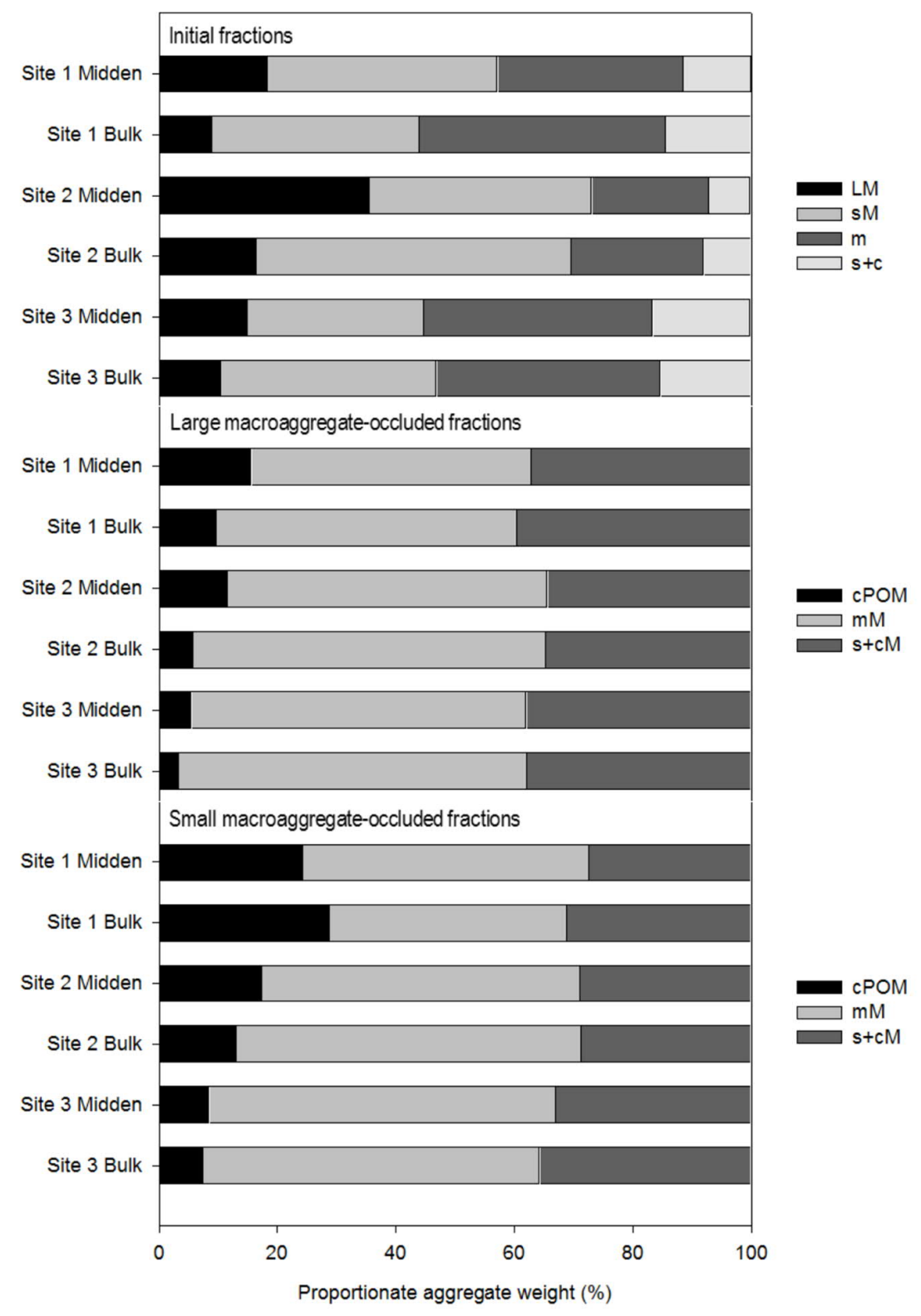

650 Fig. 1 Proportional weights $(\%)$ of the aggregate fractions ( $\mathrm{LM}=$ large macroaggregates, $\mathrm{sM}=$

651 small macroaggregates, $\mathrm{m}=$ microaggregates, $\mathrm{s}+\mathrm{c}=$ silt and clay) and microaggregate isolation

652 from large and small macroaggregates (fractions within the aggregates: cPOM=particulate organic

653 matter, $\mathrm{mM}=$ microaggregates, $\mathrm{s}+\mathrm{cM}=$ silt and clay) in soil from earthworm middens and

654 surrounding bulk soil at three study sites under no-till management.

655 


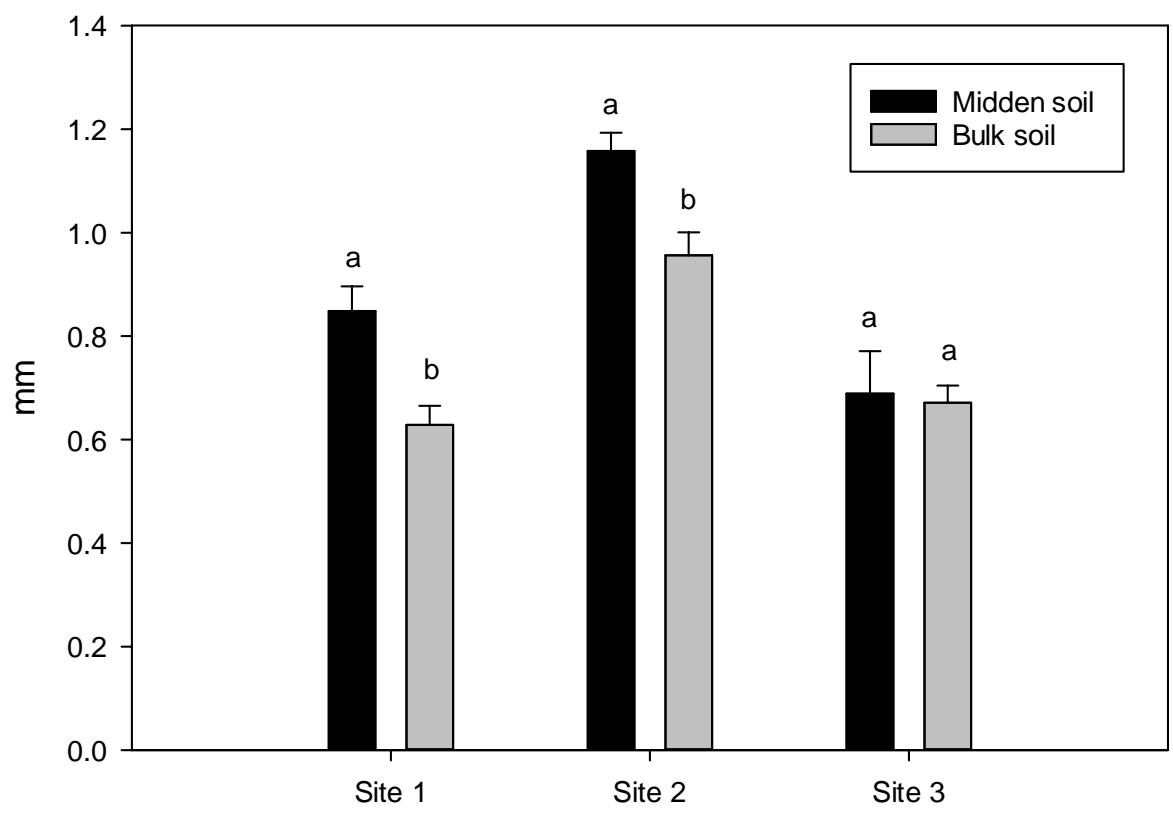

656

657 Fig. 2 Mean weight diameter (MWD; mm) of earthworm middens and surrounding bulk soil at

658 three study sites under no-till management (mean \pm standard error). Different letters denote

659 statistical differences between midden and bulk soil (linear mixed model). 


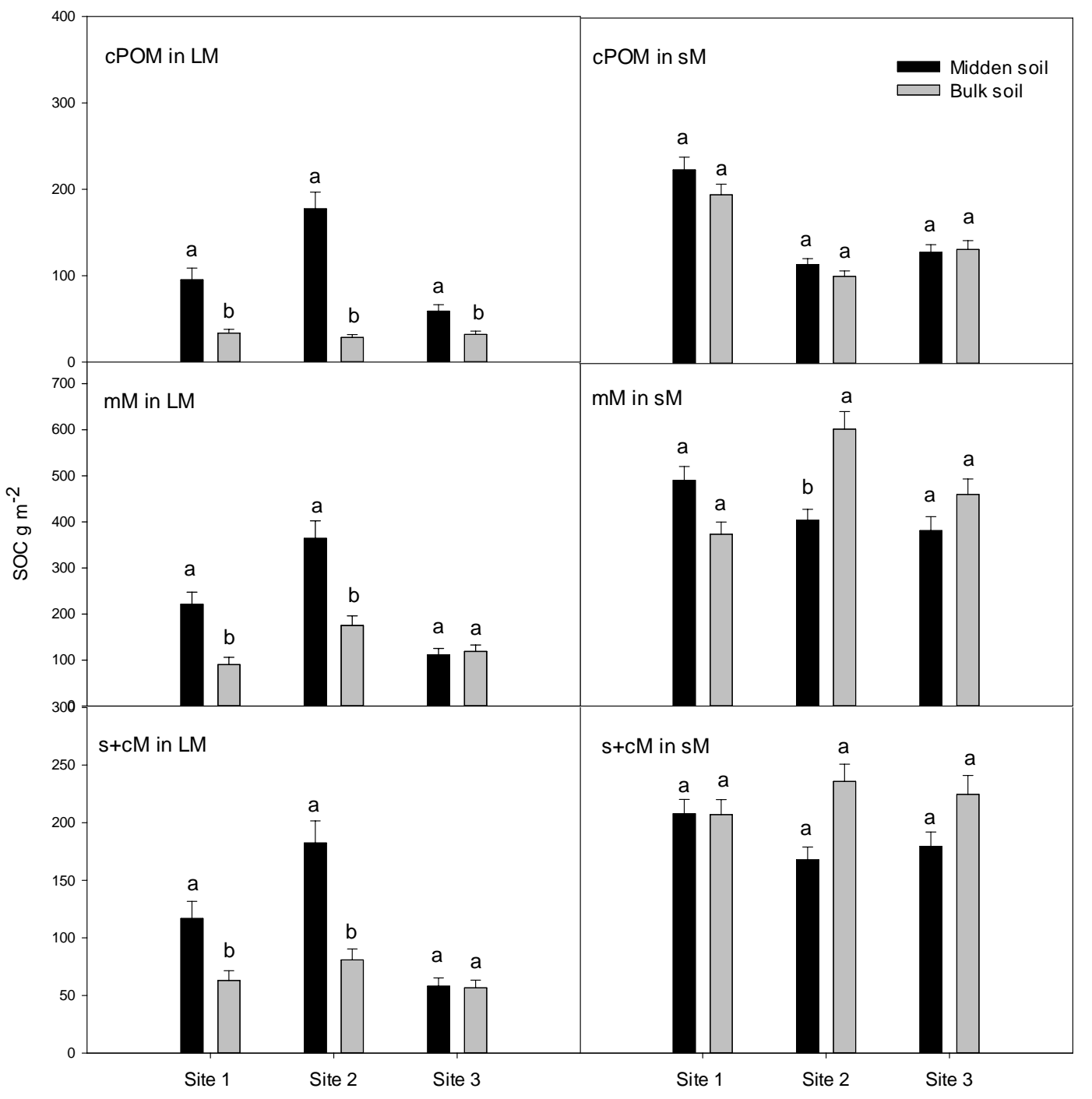

660

661 Fig. 3 Amount of soil organic carbon (SOC; $\mathrm{g} \mathrm{C} \mathrm{m}^{-2}$ ) in coarse particulate organic matter (cPOM),

662 microaggregates $(\mathrm{mM})$ and silt and clay $(\mathrm{s}+\mathrm{cM})$ within large $(\mathrm{LM})$ and small macroaggregates

$663(\mathrm{sM})$ in earthworm middens versus surrounding bulk soil at three study sites under no-till

664 management (mean \pm standard error). Different letters denote statistical differences between midden

665 and bulk soil (linear mixed model). 

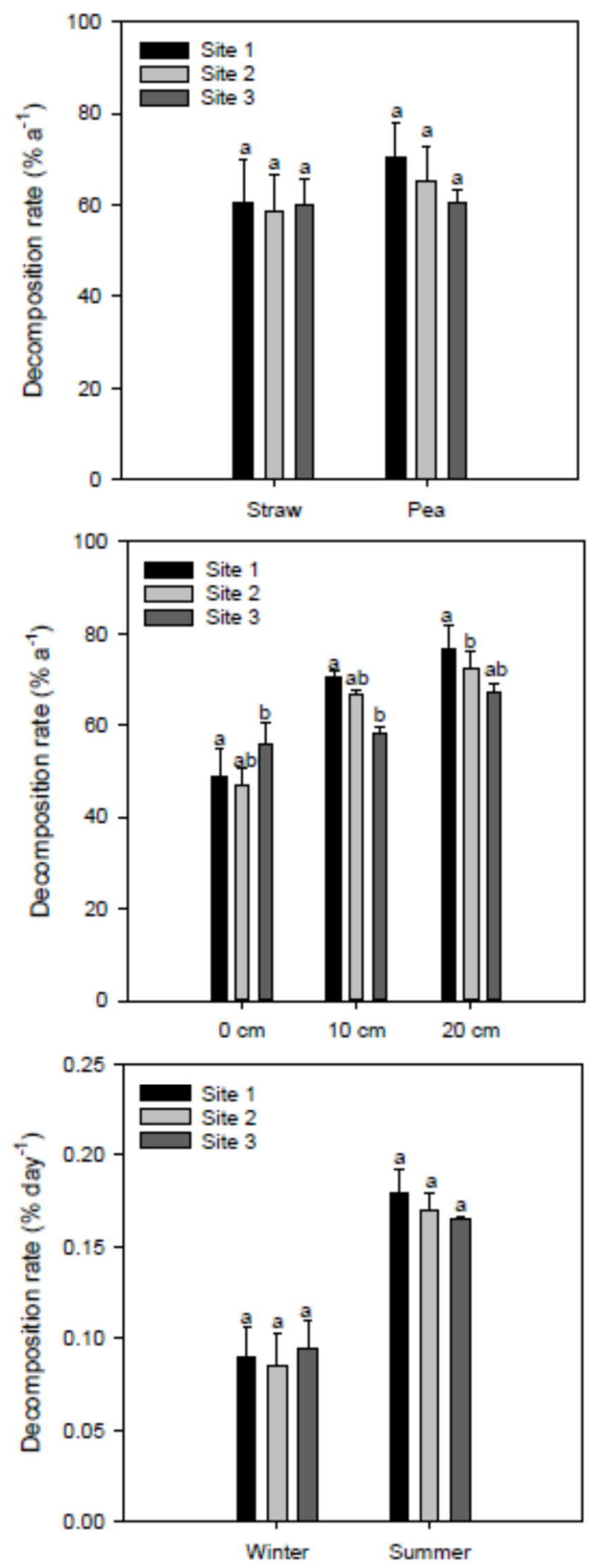

667 Fig. 4 Residue decomposition ( \pm standard error) under no-till as $\%$ of the original mass a) of barley 668 straw and pea, b) in different depths of the soil profile, c) in winter and summer. Different letters 669 denote statistical differences between sites (linear mixed model). 
Table 1

671 Site management and top soil properties (ND=not determined).

\begin{tabular}{lccc}
\hline & Site 1 & Site 2 & Site 3 \\
\hline Years under no-till & 11 & 11 & 12 \\
Fertilizer $\left(\mathrm{kg} \mathrm{N} \mathrm{ha}^{-1} \mathrm{yr}^{-1}\right)$ & 100 & 100 & 80 \\
Crop 2010 & Spring barley & Spring barley & Turnip rape \\
Yield 2010 $\left(\mathrm{kg} \mathrm{ha}^{-1}\right)$ & 2609 & 1562 & 1000 \\
Particle fractions $(\%)$ & & & \\
Clay $(<2 \mu \mathrm{m})$ & 46 & 62 & 19 \\
Silt $(2-20 \mu \mathrm{m})$ & 29 & 19 & 30 \\
Fine sand $(20-200 \mu \mathrm{m})$ & 14 & 11 & 34 \\
Coarse sand $(>200 \mu \mathrm{m})$ & 11 & 8 & 17 \\
Bulk density 0-5 $\mathrm{cm}\left(\mathrm{g} \mathrm{cm}^{-3}\right)$ & 1.33 & 1.02 & 1.37 \\
L. terrestris density $\left(\right.$ ind. $\left.{ }^{-2}\right) \dagger$ & ND & 12 & 27 \\
L. terrestris biomass $\left(\mathrm{g} \mathrm{m}^{-2}\right) \dagger$ & ND & 25 & 67 \\
\hline
\end{tabular}

672 †Data from Sep 2009; combination of hand sorting and formalin extraction methods (International

673 Organization for Standardization 2006)

$674 \quad \mp$ ND $=$ Not Determined

675

676 
Table 2

678 Amount of soil organic carbon $\left(\mathrm{g} \mathrm{C} \mathrm{m}^{-2}\right)$ within the soil fractions acquired from wet sieving of whole soil of the top $5 \mathrm{~cm}$ layer from earthworm middens and surrounding bulk soil (mean \pm standard error) at three study sites under no-till management.

\begin{tabular}{|c|c|c|c|c|c|c|}
\hline & \multicolumn{2}{|l|}{ Site 1} & \multicolumn{2}{|l|}{ Site 2} & \multicolumn{2}{|l|}{ Site 3} \\
\hline & Midden soil & Bulk soil & Midden soil & Bulk soil & Midden soil & Bulk soil \\
\hline Total soil & $2020 \pm 50^{\mathrm{a}}$ & $1900 \pm 48^{b}$ & $1800 \pm 51^{\mathrm{a}}$ & $1660 \pm 25^{b}$ & $1730 \pm 85^{\mathrm{a}}$ & $1690 \pm 77^{b}$ \\
\hline LM & $440 \pm 45^{a}$ & $196 \pm 17^{b}$ & $737 \pm 59^{a}$ & $305 \pm 30^{b}$ & $229 \pm 21^{\mathrm{a}}$ & $207 \pm 20^{a}$ \\
\hline sM & $859 \pm 31^{\mathrm{a}}$ & $761 \pm 72^{\mathrm{a}}$ & $657 \pm 48^{\mathrm{a}}$ & $895 \pm 34^{\mathrm{a}}$ & $663 \pm 53^{a}$ & $834 \pm 56^{\mathrm{a}}$ \\
\hline $\mathrm{m}$ & $555 \pm 44^{\mathrm{a}}$ & $758 \pm 85^{\mathrm{a}}$ & $304 \pm 24^{\mathrm{a}}$ & $329 \pm 32^{\mathrm{a}}$ & $519 \pm 42^{\mathrm{a}}$ & $492 \pm 48^{a}$ \\
\hline $\mathrm{s}+\mathrm{c}$ & $177 \pm 14^{\mathrm{a}}$ & $226 \pm 22^{\mathrm{a}}$ & $98 \pm 8^{a}$ & $112 \pm 11^{\mathrm{a}}$ & $215 \pm 20^{a}$ & $220 \pm 22^{a}$ \\
\hline
\end{tabular}

681

Table 3

Statistically significant differences between the treatments (linear mixed model) within a study site are denoted by different lower case letters $\left({ }^{a, b}\right)$ and bold font

$$
\begin{aligned}
& \text { LM = large macroaggregates } \\
& \mathrm{sM}=\text { small macroaggregates } \\
& \mathrm{m}=\text { microaggregates } \\
& \mathrm{s}+\mathrm{c}=\text { silt and clay }
\end{aligned}
$$

Amount of $\mathrm{N}\left(\mathrm{g} \mathrm{N} \mathrm{m}^{-2}\right)$ within soil fractions acquired from wet sieving of whole soil and fractions isolated from large and small macroaggregates of the top $5 \mathrm{~cm}$ layer from earthworm middens and surrounding bulk soil at three study sites under no-till management (mean \pm standard error).

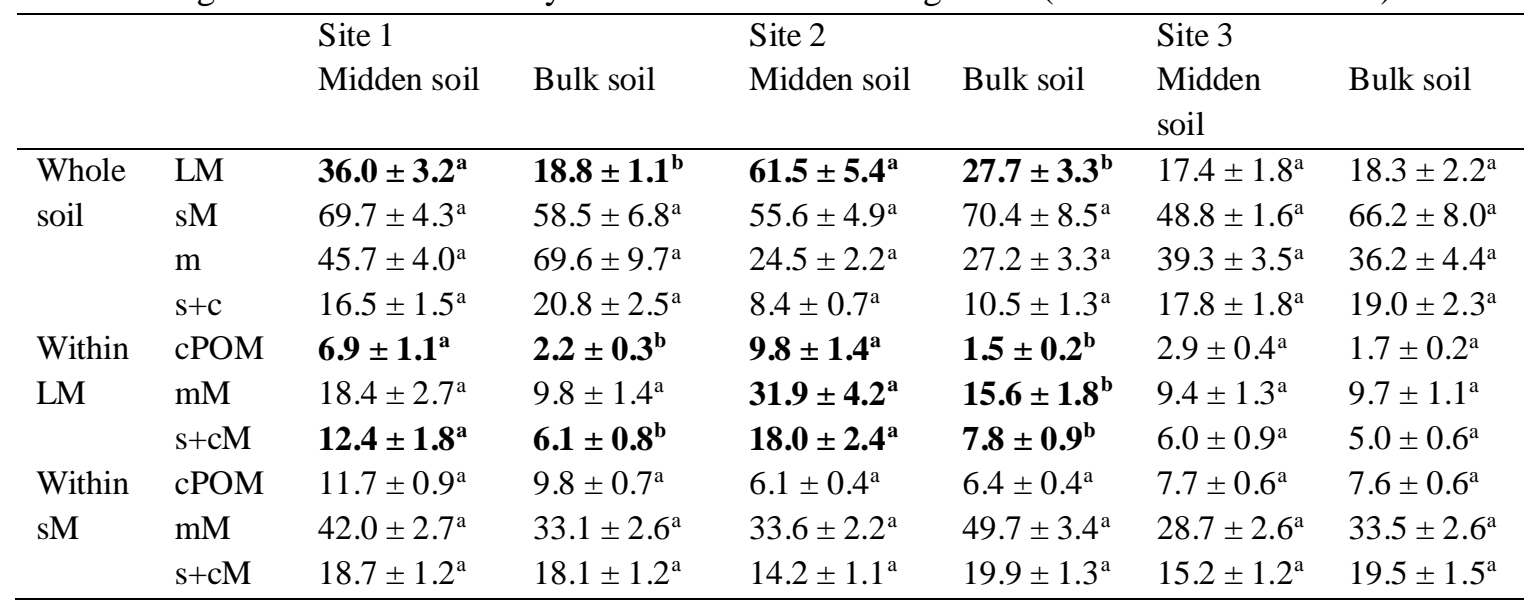

Statistically significant differences between different treatments (linear mixed model) within a study site are denoted by different lower case letters $\left({ }^{(a, b}\right)$ and bold font

$\mathrm{LM}=$ large macroaggregates

$\mathrm{sM}=$ small macroaggregates

$\mathrm{m}(\mathrm{M})=$ microaggregates (within macroaggregates)

$\mathrm{s}+\mathrm{c}(\mathrm{M})=$ silt and clay (within macroaggregates)

$\mathrm{cPOM}=$ coarse particulate organic matter 